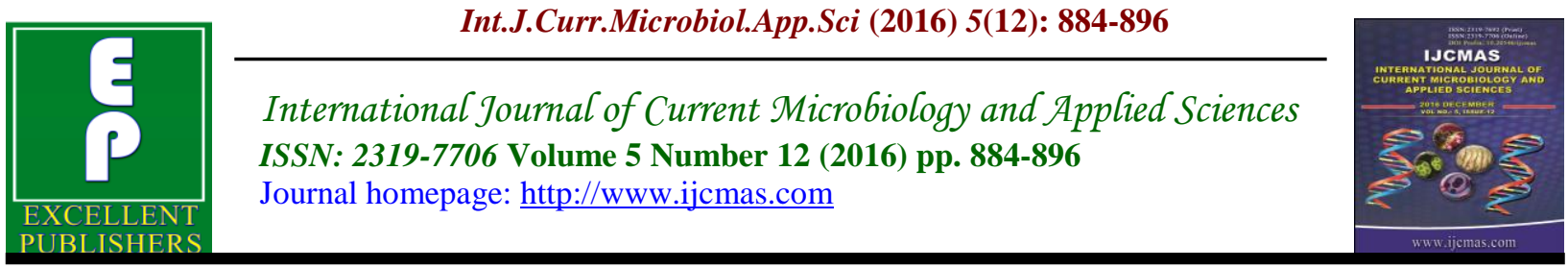

Original Research Article

http://dx.doi.org/10.20546/ijcmas.2016.512.096

\title{
Assessment of Herbaceous Seed Bank and Soil Organic Matter Content in the Three Different Sites in Semi - Arid Rangelands at Eldebeibat Area (South Kordofan State) - Sudan
}

\author{
Abdelrahim Omer Abdelrahim ${ }^{1} *$, Nawal Khidir Nasr Alamin² and \\ Abdelaziz Karamalla Gaiballa ${ }^{2}$ \\ ${ }^{1}$ University of Zalingei, College of Forestry Sciences, Central Darfur State, Sudan \\ ${ }^{2}$ Sudan University of Science and Technology, College of Forestry and Range Science, \\ Khartoum, Sudan \\ *Corresponding author
}

Keywords

Soil seed bank, soil organic matter, live seeds, dead seeds, clay, sandy, gardud, relative frequency.

\section{Article Info}

Accepted:

15 November 2016

Available Online:

10 December 2016
A B S T R A C T

This study was carried out at Eldebeibat area in El Dilling locality - South Kordofan State during the two rainy seasons of (2013 and 2014) the aim of this study was to assess the seed bank of herbaceous species and soil organic matter content. Three sites were selected namely; clay, sandy and gardud ${ }^{1}$ site. Four transects were delineated using 100 meter tape distributed in the each site and then ten quadrats $1 \times 1 \mathrm{~m}$ were used to observes plants frequency $\%$ and ten soil samples $10 \times 10 \mathrm{~cm}$ with depth $10 \mathrm{~cm}$ were taken along each transect to estimate relative seeds density and soil organic matter. The seeds reference were taken from standing plant species and then compared with seeds bank. Questionnaire was designed to collect primary data about the history of plant species, total of (372) respondents were selected randomly to obtain information about the invader species in the study area. The row data of seed bank were analyzed by using the floating Method, (Ramadan, 2001) and standard equations of seeds density and Excel program were used; the organic matter data were analyzed by using Furnace Method (Reddy, 2002). The results shows that the seed bank in clay site scored the lowest seeds density for both live and dead seeds, sandy site scored the highest density for both live and dead seeds) followed by gardud site. The clay site dominated by Schoenfeldia gracilis live seeds density and by Chloris gayana dead seeds density, sandy site dominated by Zornia glochidiata live seeds density and Echinochloa colona dead seeds density, while gardud site dominated by Vossia cuspidata live and dead seeds density. Soil organic matter content at the three sites scored low percentage. The study recommended to increase soil organic matter content, through planting legumes trees and shrubs and broadcasting seeds of legumes of herbaceous species in the study area and avoids early grazing at the rainy season. 


\section{Introduction}

\section{Soil seed bank}

Soil seed banks are important components of vegetation dynamics affecting both ecosystem resistance and resilience. In arid ecosystems seed banks are characterized by high spatial and temporal variability (Thompson, 1987; Rundel and Gibson, 1996). The studies on population dynamics have the objective to determine their size throughout time and factors that influence their size (Saavedra, 1994). In agro ecosystems, where the soil is disturbed frequently, the soil seed bank acts to stabilize and ensure species survival (Roberts, 1981). The input is determined by the seed "rain". This way of dispersion includes passive forms, mechanical ejection of seeds, fire, wind, water and animals. The result from physiological answer of plants to environmental factors, that induces the germination, seed burial or re- dispersion of the seeds, and predation of the seeds by insects, pathogens, and other animals (Carvalho et al.,1995). Land preparation and crop rotation are the two primary agricultural practices that generate impacts on weed seed banks (Ball, 1992). The land preparation practices are used in order to control weeds, break soil surface hardness, and increase aeration; the seed germination is stimulated because of the seed dormancy break by light, alternated temperature, water and nitrate ions (Cavers and Benoit, 1989).The type of land preparation influences the seed dispersion in the soil profile; the management at same depth, favor an uniform distribution of the seeds in the soil profile, finding lower seed populations deeper in the soil (Dessaint et al., 1990). Ball, (1992) comparing land preparation systems, disc plow versus disc harrow, observed the predominance of weed seeds closer to the surface after disc harrowing. (Clements et al., (1996) studied the influence of land preparation types over the seed bank and found that more than $70 \%$ of the seeds were presented in the layer of 0$5 \mathrm{~cm}$ in plots where no mechanical method was used, and 30\% for plots mechanically managed. Some weed species may present higher intensity of emergence in the no till planting than in the conventional till. Carmona, (1992) stated that no till and superficial tillage tends to reduce the amount of seeds at the soil surface shed by plants, since there is induction in the germination or loss of viability. The presence of seeds at the superficial layer of the soil and frequent cultivation are factors that reduce the seed bank rapidly. This situation can facilitate seed predation by exposure of seeds to variations in temperature and humidity, and breaking their dormancy. However, the speed of soil seed bank depletion depends on the seed production of the species (Yenish et al., 1992).

For the seeds that are buried in the soil profile, where the conditions are more uniform, the action of external factors is less intense. The maintenance of viability will depend basically on the seed characteristics (Martins and Silva, 1994).

The use of herbicides can also influence the species composition of the seed bank, and may increase or decrease it, depending on the chemicals used (Ball, 1992). In general, it can be said that interaction among herbicides, land preparation and cultural practice have altered the size and nature of seed banks (Roberts, 1981).

\section{Soil organic matter}

Organic matter is a reservoir of nutrients that can be released to the soil. Each percent of organic matter in the soil releases 20 to 30 pounds of nitrogen 4.5 to 6.6 pounds of $\mathrm{P}_{2} \mathrm{O}_{5}$, and 2 to 3 pounds of sulfur per year. The nutrient release occurs predominantly in 
the spring and summer, so summer crops benefit more from organic-matter mineralization than winter crops. .(reference)

Organic matter behaves somewhat like a sponge, with the ability to absorb and hold up to 90 percent of its weight in water. A great advantage of the water-holding capacity of organic matter is that the matter will release most of the water that it absorbs to plants. In contrast, clay holds great quantities of water, but much of it is unavailable to plants. .(reference)

Organic matter causes soil to clump and form soil aggregates, which improves soil structure with better soil structure permeability (infiltration of water through the soil) improves in turn improving the soil's ability to take up and hold water soil organic matter from 1 to 3 percent can reduce erosion 20 to 33 percent because of increased water infiltration and stable soil aggregate formation caused by organic matter (Barber; 1984, Brady; 1974, Plaster, 1996; Tisdale and Nelson, 19751.3). Frequency is typically used to evaluate plant species distribution over an area and/or change in abundance of species over time due to management. Frequency is the percentage of quadrates in which the species occurs (Society for Range management, 1989).

\section{Materials and Methods}

\section{The study area}

The study was conducted in Eldebeibat area in El Dilling locality - South Kordofan State (Figure 1). It is a part of South Kordofan State that was affected by desertification phenomenon, which spread from North Kordofan State up to the area under focus. The area lies between latitude $11^{\circ} 45^{\prime}-12^{\circ}$ $49^{\prime} \mathrm{N}$ and $25^{\circ} 29^{\prime}-30^{\circ} 0 \mathrm{E}$. The area is about $5700 \mathrm{Km}^{2}$ and constitute $27 \%$ of locality area and $7.3 \%$ of the total area of the State (Musa, 2001) figure (1).

\section{Sampling}

The study area was divided into three sites depended upon soil types such as clay, sandy, and gardud, which are represented the main types of rangelands in the study area. Two soil samples were taken of each block to determination soil organic matter percentage. The $100 \mathrm{~m}$ transects were distributed randomly within each site, and then ten quadrats were taken along each transect to estimate soil seeds bank and observe frequency of stand plants species.

\section{Seed bank of herbaceous species assessment}

\section{Seed bank sampling}

To assess seed bank, ten soil samples were taken randomly in each site in $10 \times 10 \mathrm{~cm}$ at $10 \mathrm{~cm}$ depth, and put in paper bags. The samples were mixed thoroughly, and subsamples of $250 \mathrm{~g}$ were prepared for seeds extraction.

\section{Seeds extraction}

Preliminary washing of the soil samples were done by using sieves of $1.0,0.5$, and $0.25 \mathrm{~mm}$ pore size. The technique comprised initial washing of the soil, floatation, and then separation of live seeds based on their density using $\mathrm{Ca} \mathrm{Cl}_{2}$ solution. Each soil sample (250g) was placed and filtered through three sieves and washed for $20 \mathrm{~min}$. The residuals in the three sieves were washed by about $250 \mathrm{ml}$ of water, then transferred into $500 \mathrm{ml}$ beaker and stirred. The floating organic matter including dead seeds was filtered by using a funnel with 
filter paper inside it; the funnel is placed into one litter side arm flask to aid filtration. The filtered residue on the filter paper was transferred to $9 \mathrm{~cm}$. Petri - dish and the organic matter retrieved included mainly dead seeds. About $250 \mathrm{ml}$ of $\mathrm{CaCl}_{2}(1.5 \mathrm{~g} / \mathrm{ml}$ of water) was added to the same sample residues, and let each sample residues for 40 min into a beaker. The floated material after stirring included mainly live seeds (Ramadan, 2001). The washing of samples was done at chemistry laboratory at Sudan University of Science and Technology, College of Forestry and Range Science, Khartoum, Sudan.

\section{Seeds identification}

Extracted seeds were identified through comparison with reference samples of seeds collected from plants growing in the study area, using a microscope and lenses. The identified seeds in each sample where recorded and counted (Ramadan, 2001).

Percent of live seeds $=\frac{\text { Total live seeds }}{\text { Total of all seeds (live \& dead })} \times 100$

Percent of dead seeds $=\frac{\text { Total dead seeds }}{\text { Total of all seeds (live \& dead) }} \times 100$

Number of seeds $/ \mathrm{m}^{2}=\frac{\text { Number of seeds } / \text { depthx } 100 \times 100}{\text { quadrat area }\left(\mathrm{m}^{2}\right) \text { xnumber of quadrat } / \text { depth }}$

\section{Soil organic matter determination}

The organic matter is the plant and animal residues incorporated into the soil, such as parts of leaves, manure, or plant parts.

\section{Equipment}

Muffle furnace, Balance, Porcelain dish, Spatula and Tongs

The furnace method (Reddy, 2002) was used to determine organic matter percentage in the soil; five soil samples were taken from each block (ten samples for each site) by using augur to take samples at depth $20 \mathrm{~cm}$ and then mixed thoroughly to take sub sample of $50 \mathrm{~g}$ was taken from each sample which was taken in the field and dried in oven and weighed. Also the sub samples were burned at furnace.

\section{Procedure at laboratory}

(1) Determined and recorded the mass of an empty, clean, and dry porcelain dish (MP).

(2) Placed a part of or the entire oven-dried test sample of soil from the moisture content experiment (Expt.1) in the porcelain dish and determined and recorded the mass of the dish and soil sample (MPDS).

(3) Placed the dish in a muffle furnace gradually increased the temperature in the furnace to $440^{\circ} \mathrm{C}$. Leave the soil sample in the furnace overnight.

(4) Removed carefully the porcelain dish using the tongs (the dishes very hot), and allowed it to cool into room temperature.

5- Determined and recorded the mass of the dish containing the ash (burned soil) (MpA).

\section{Steps of organic matter calculation}

(1) Determined the mass of the dry soil. MD=MPDS-MP

(2) Determined the mass of the ashed (burned) soil.

MA=MPA-MP

(3) Determined the mass of organic matter $\mathrm{MO}=\mathrm{MD}-\mathrm{MA}$

(4) Determined the organic matter 
percentage (content). (Reddy, 2002)

$\mathrm{OM} \%=\frac{\mathrm{MO}}{\mathrm{MD}} \times 100$

\section{Relative frequency percentage of each plants species}

To measure relative frequency four transects length of each one $(100 \mathrm{~m})$ were distributed randomly in each block and ten quadrates were taken along each transects.

Plant frequency was calculated by counting species, which occur within each quadrate and record their names only not their number. The following equation was used to calculate relative frequency (Daubenmire, 1969).

Frequancy\%

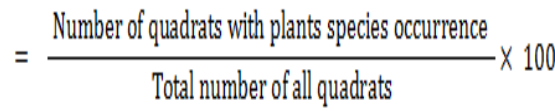

\section{Results and Discussion}

\section{Soil seed bank density}

Table (1) illustrates average seeds densities $/ \mathrm{m}^{2}$ live and dead and percentage of live and dead seeds of the three sites in depth $(0-10 \mathrm{~cm})$, the results showed site clay site scored the lowest seeds density for both live and dead such as live seeds $\left(1460 \mathrm{seed} / \mathrm{m}^{2}\right) 43 \%$, and $\left(1920 \mathrm{seed} / \mathrm{m}^{2}\right)$ $57 \%$ respectively, sandy site scored the highest seeds density per square meter, $\left(3980 \mathrm{seed} / \mathrm{m}^{2}\right)$ such as live seeds represented 57\%, $\left(3320\right.$ seed $\left./ \mathrm{m}^{2}\right) \quad 43 \%$ represented dead seeds and gardud site followed the sandy in seeds density live seeds scored $\left(3540 \mathrm{seed} / \mathrm{m}^{2}\right) 54 \%$, dead seeds recorded (3040seed $\left./ \mathrm{m}^{2}\right) 46 \%$.

\section{Dominant species in seed bank}

The dominant species in seeds bank at three sites clay, sandy and gardud respectively whether alive or dead illustrates in tables (2, 3 and 4), in the clay site dominated live seeds such as Schoenfeldia gracilis $\left(29 \mathrm{seed} / \mathrm{m}^{2}\right)$, Chloris gayana $\left(20 \mathrm{seed} / \mathrm{m}^{2}\right)$, Zornia glochidiata $\left(13 \mathrm{seed} / \mathrm{m}^{2}\right)$, Echinochloa colona $\left(10 \mathrm{seed} / \mathrm{m}^{2}\right)$ and Alycicarpus vaginalis $\left(1 \mathrm{seed} / \mathrm{m}^{2}\right)$, while dominant dead seeds included Echinochloa colona $\left(30 \mathrm{seed} / \mathrm{m}^{2}\right), \quad$ Chloris preiurii $\left(18 \mathrm{seed} / \mathrm{m}^{2}\right)$ and Vossia cuspidata $\left(5 \mathrm{seed} / \mathrm{m}^{2}\right)$, sandy site dominated by Zornia glochidiata $\left(155 \mathrm{seed} / \mathrm{m}^{2}\right), \quad$ Echinochloa colona $\left(13 \mathrm{seed} / \mathrm{m}^{2}\right), \quad$ Dactyloctenium aegyptium $\left(13 \mathrm{seed} / \mathrm{m}^{2}\right), \quad$ Alycicarpus vaginalis $\left(7 \mathrm{seed} / \mathrm{m}^{2}\right)$ and Acanthospermum hispidum $\left(5 \mathrm{seed} / \mathrm{m}^{2}\right)$ in live seeds, the dominant dead seeds included Echinochloa colona $\left(90 \mathrm{seed} / \mathrm{m}^{2}\right)$, Zornia glochidiata $\left(64 \mathrm{seed} / \mathrm{m}^{2}\right)$, Dactylotenium aegyptium (6seed $\left./ \mathrm{m}^{2}\right), \quad$ Alycicarpus vaginalis (1seed $\left./ \mathrm{m}^{2}\right)$, Cenchrus biflorus $\left(1 \mathrm{seed} / \mathrm{m}^{2}\right)$ and Oldenlandia senegalensis $\left(1 \mathrm{seed} / \mathrm{m}^{2}\right)$. While gardud site dominated by Vossia cuspidata $\quad\left(91 \mathrm{seed} / \mathrm{m}^{2}\right), \quad$ Echinochloa colona $\left(76 \mathrm{seed} / \mathrm{m}^{2}\right), \quad$ Chloris preiurii $\left(31 \mathrm{seed} / \mathrm{m}^{2}\right)$, Chloris gayana $\left(4 \mathrm{seed} / \mathrm{m}^{2}\right)$, Alycicarpus vaginalis $\left(1 / \mathrm{seedm}^{2}\right)$, Schoenfeldia gracilis $\left(1 \mathrm{seed} / \mathrm{m}^{2}\right)$ and Senna obtusifolia $\left(1 \mathrm{seed} / \mathrm{m}^{2}\right)$ such as live seeds, dominant dead seeds included Vossia cuspidata $\left(128 \mathrm{seed} / \mathrm{m}^{2}\right)$, Chloris preiurii $\left(14 \mathrm{seed} / \mathrm{m}^{2}\right)$ and Zornia glochidiata (6seed $\left./ \mathrm{m}^{2}\right), \quad$ Alycicarpus vaginalis $\left(2 \mathrm{seed} / \mathrm{m}^{2}\right)$, Cassia senna $\left(1 \mathrm{seed} / \mathrm{m}^{2}\right)$ and Senna obtusifolia $\left(1 \mathrm{seed} / \mathrm{m}^{2}\right)$.

The three sites were dominated by different seeds species in both seasons, that attributed to variation of soil type, soil topography, palatability of species particularly in milk stage, that lead livestock avoid some species when are reached to this stage and level of grazing.

Five dominant species in both (relative frequency $\%$ and soil seed bank) at three sites

Table (4) illustrates five dominated species 
at three sites in relative frequency and seeds bank respectively. Clay site dominated by these species Schoenfeldia gracilis (61\%), Zornia glochidiata (40.5\%), Dactyloctenium aegyptium (40\%), Chloris gayana (28.5\%), and Chloris preuirii (25\%). While the species consider dominant in seed bank such as Schoenfeldia gracilis $\left(29 \mathrm{seed} / \mathrm{m}^{2}\right)$, Chloris gayana $\left(20 \mathrm{~m}^{2}\right)$, Zornia glochidiata $\left(13 \mathrm{seed} / \mathrm{m}^{2}\right)$, Echinochloa colona $\left(10 \mathrm{~m}^{2}\right)$, and Alycicarpus vaginalis $\left(1 \mathrm{seed} / \mathrm{m}^{2}\right)$. Sandy site dominated in vegetation cover with Zornia glochidiata (89.5\%), Eragrostis spp $(73.5 \%)$, Oldenlandia senegalensis $(67 \%)$, Echinochloa colona (58\%), and Dactyloctenium aegyptium (41.5\%). The dominant species in seed bank in sandy site such as Zornia glochidiata $\left(155 \mathrm{seed} / \mathrm{m}^{2}\right)$, Echinochloa colona $\left(13 \mathrm{seed} / \mathrm{m}^{2}\right)$, Dactyloctenium aegyptium $\left(13 \mathrm{seed} / \mathrm{m}^{2}\right)$, Alycicarpus vaginalis $\left(7 \mathrm{seed} / \mathrm{m}^{2}\right)$, and Acanthospermum hispidum $\left(5 \mathrm{seed} / \mathrm{m}^{2}\right)$. Gardud site dominated in vegetation cover by Vossia cuspidata (58.5\%), Schoenfeldia gracilis (35.5\%), Chloris preurii (21\%), Zornia glochidiata (18\%), and Dactyloctenium aegyptium (16.5\%), while dominated in the seed bank in gardud site with Vossia cuspidata (91 seed $\left./ \mathrm{m}^{2}\right)$, Echinochloa colona $\left(76 \mathrm{seed} / \mathrm{m}^{2}\right)$, Chloris preurii $\left(31 \mathrm{seed} / \mathrm{m}^{2}\right), \quad$ Chloris gayana $\left(4 \mathrm{seed} / \mathrm{m}^{2)}\right.$, and Alycicarpus vaginalis $\left(3 \mathrm{seed} / \mathrm{m}^{2}\right)$. In clay site Zornia glochidiata was appeared in vegetation cover through relative frequency and in seed bank, but this species not prefer by most kinds of animals in the area. Echinochloa colona and Alycicarpus vaginalis are appeared in seed bank and disappeared on vegetation cover that attributed to overgrazing and selective of these species. Dactyloctenium aegyptium occurred in vegetation cover and absent in seed bank, that due to early grazing, which lead to damaging seeds of grasses. In sandy site Zornia glochidiata considered dominant species in vegetation cover and seed bank, that indictor of range deterioration in the area and addition to appearance of undesirable species such as Acanthospermum hispidum, Oldenlandia senegalensis was appeared in vegetation cover and absent in seed bank. Gardud site also have same problems, which mentioned in above sites, in this Echinochloa colona and Alycicarpus vaginalis occurred in seed bank and disappeared on vegetation cover, which that may be these species have problem in germination process.

\section{Soil organic matter percentages}

Figure (2) demonstrates percentage of soil organic matter content in the three sites (clay, sandy and gardud site respectively); the values $2.7 \%, 1.7 \%$ and $1.4 \%$. The gardud site scored the lowest organic matter, when compared with other sites (clay and sandy), this attributed to plant cover percent, level of grazing pressure, lake of plants litters on the soil surface, and absence of legumes species in the plant community in this site.

\section{Invader herbaceous species}

Through interview with respondents in the area, are confirmed occurrences of invader species such as Zornia glochidiata, Chloris preurii, Eragrostis spp, Sida cordofolia, Aristida spp, Acanthospermum hispidum, Senna obtusifolia, Xanthium brsilicum, Senna occidentalis, Amaranthus viridis, and Datura stramonium. Majority of these species are undesirable for most livestock in area and consider strong indicator of rangeland deterioration, that may be attributed to intensive and early grazing. Moreover these species require controlling by suitable means table (6). This result confirmed the findings of (Todd and Hoffman, 1999, Cordon, 2007 and Fashir, 2014) stated that, Continuous intense 
grazing leads to vegetation changes, such as the replacement of palatable grasses by less palatable plant species, replacement of perennial grasses by annuals, bush encroachment, lower standing biomass and reduced basal cover.

Table.1 Density of live and dead seeds/m2 and percent of the three sites at

Eldebeibat area (South Kordofan State)

\begin{tabular}{|l|l|l|l|l|}
\hline \multirow{2}{*}{ Sites } & \multicolumn{2}{c|}{ Seed density $/ \mathrm{m}^{2}$} & \multicolumn{2}{c|}{ Percent } \\
\cline { 2 - 5 } & Live & Dead & Live & Dead \\
\hline Clay & 1460 seed $/ \mathrm{m}^{2}$ & 1920 seed $/ \mathrm{m}^{2}$ & $43 \%$ & $57 \%$ \\
\hline Sandy & 3320 seed $/ \mathrm{m}^{2}$ & $3320 \mathrm{seed} / \mathrm{m}^{2}$ & $57 \%$ & $43 \%$ \\
\hline Gardud & $3540 \mathrm{seed} / \mathrm{m}^{2}$ & $3040 \mathrm{seed} / \mathrm{m}^{2}$ & $54 \%$ & $46 \%$ \\
\hline
\end{tabular}

Table.2 Average lives and dead seeds density/m2 and relative frequency\% in the clay site at Eldebeibat area (South Kordofan State)

\begin{tabular}{|l|l|c|c|c|}
\hline \multirow{2}{*}{ Species } & \multirow{2}{*}{ Habit } & \multicolumn{2}{c|}{ Seeds/m } & \multirow{2}{*}{ Frequency\% } \\
\cline { 3 - 4 } & & Live & Dead & \\
\hline Schoenfeldia gracilis & Grass & 29 & 0.0 & 61 \\
\hline Chloris gayana & Grass & 20 & 32 & 29 \\
\hline Zornia glochidiata & Forbs & 13 & 4 & 41 \\
\hline Echinochloa colona & Grass & 10 & 30 & 19 \\
\hline Dactyloctenium aegyptium & Grass & 0.0 & 7 & 40 \\
\hline Chloris preuirii & Grass & 0.0 & 18 & 25 \\
\hline Vossia cuspidata & Grass & 0.0 & 5 & 0.0 \\
\hline Alycicarpus vaginalis & Forbs & 1 & 0.0 & 0.0 \\
\hline Cenchrus biflorus & Grass & 0.0 & 0.0 & 0.0 \\
\hline Oldenlandia senegalensis & Forbs & 0.0 & 0.0 & 12 \\
\hline Acanthospermum hispidum & Forbs & 0.0 & 0.0 & 1 \\
\hline Senna obtusifolia & Forbs & 0.0 & 0.0 & 20 \\
\hline Solanum dubium & Forbs & 0.0 & 0.0 & 8 \\
\hline Abutilon angulatum & Forbs & 0.0 & 0.0 & 1 \\
\hline Cyperus rotandus & Like grass & 0.0 & 0.0 & 1 \\
\hline Sesamum alatum & Forbs & 0.0 & 0.0 & 1 \\
\hline Aristida spp & Grass & 0.0 & 0.0 & 6 \\
\hline Walhteria indica & Forbs & 0.0 & 0.0 & 4 \\
\hline Corchorus olitorus & Forbs & 0.0 & 0.0 & 2 \\
\hline Sida cordofolia & Forbs & 0.0 & 0.0 & 2 \\
\hline Pennisetum pedicellatum & Grass & 0.0 & 0.0 & 1 \\
\hline Digitaria gayana & Grass & 0.0 & 0.0 & 6 \\
\hline Tribulus trestris & Forbs & 0.0 & 0.0 & 1 \\
\hline Ipomea spp & Forbs & 0.0 & 0.0 & 3 \\
\hline Ipmea cordofana & Forbs & 0.0 & 0.0 & 1 \\
\hline Total seeds & & $\mathbf{7 3}$ & $\mathbf{9 6}$ & \\
\hline Total seeds/m & & $\mathbf{1 4 6 0}$ & $\mathbf{1 9 2 0}$ & \\
\hline & & & & \\
\hline
\end{tabular}


Table.3 Average live and dead seeds density/m2 and frequency\% in the sandy site at Eldebeibat area (South Kordofan State)

\begin{tabular}{|l|c|c|c|c|}
\hline \multirow{2}{*}{ Species } & \multirow{2}{*}{ Habit } & \multicolumn{2}{c|}{ Seeds/m } & \multirow{2}{*}{ Frequency\% } \\
\cline { 3 - 4 } & & Live & Dead & \\
\hline Schoenfeldia gracilis & Grass & 0.0 & 0.0 & 1 \\
\hline Chloris gayana & Grass & 0.0 & 0.0 & 2 \\
\hline Zornia glochidiata & Forbs & 155 & 64 & 90 \\
\hline Echinochloa colona & Grass & 19 & 90 & 58 \\
\hline Dactyloctenium aegyptium & Grass & 13 & 6 & 42 \\
\hline Eragrotis spp & Grass & 0.0 & 0.0 & 74 \\
\hline Sida cordofolia & Forbs & 0.0 & 0.0 & 33 \\
\hline Alycicarpus vaginalis & Grass & 7 & 1 & 15 \\
\hline Cenchrus biflorus & Forbs & 1 & 0.0 & 16 \\
\hline Oldenlandia senegalensis & Grass & 0.0 & 1 & 67 \\
\hline Acanthospermum hispidum & Forbs & 5 & 1 & 1 \\
\hline Senna obtusifolia & Forbs & 0.0 & 1 & 0.0 \\
\hline Walhteria indica & Forbs & 0.0 & 0.0 & 7 \\
\hline Digitaria gayana & Grass & 0.0 & 0.0 & 9 \\
\hline Ipomea spp & Forbs & 0.0 & 0.0 & 24 \\
\hline Fimbristylis dicotomo & Like grass & 0.0 & 0.0 & 15 \\
\hline Commelinia sabulata & Forbs & 0.0 & 0.0 & 2 \\
\hline Aristida spp & Grass & 0.0 & 0.0 & 23 \\
\hline Sesamum alatum & Forbs & 0.0 & 0.0 & 1 \\
\hline Pennisetum pedicellatum & Grass & 0.0 & 0.0 & 8 \\
\hline Cyperus rotandus & Like grass & 0.0 & 0.0 & 1 \\
\hline Total seeds & & $\mathbf{1 9 9}$ & $\mathbf{1 6 6}$ & \\
\hline Total seeds/m ${ }^{2}$ & & $\mathbf{3 9 8 0}$ & $\mathbf{3 3 2 0}$ & \\
\hline
\end{tabular}

Table. 4 shows average live and dead seeds density/m 2 and frequency percentage in the gardud site at Eldebeibat area (South Kordofan State)

\begin{tabular}{|l|c|c|c|c|}
\hline \multirow{2}{*}{ Species } & \multirow{2}{*}{ Habit } & \multicolumn{2}{c|}{ Seeds/m } & \multirow{2}{*}{ Frequency\% } \\
\cline { 3 - 4 } & & Live & Dead & \\
\hline Schoenfeldia gracilis & Grass & 1 & 0.0 & 36 \\
\hline Chloris gayana & Grass & 4 & 0.0 & 13 \\
\hline Zornia glochidiata & Forbs & 0.0 & 6 & 18 \\
\hline Echinochloa colona & Grass & 76 & 0.0 & 12 \\
\hline Dactyloctenium aegyptium & Grass & 0.0 & 0.0 & 17 \\
\hline Chloris preuirii & Grass & 3 & 14 & 21 \\
\hline Vossia cuspidata & Grass & 91 & 128 & 59 \\
\hline Alycicarpus vaginalis & Grass & 1 & 2 & 0.0 \\
\hline Oldenlandia senegalensis & Grass & 0.0 & 0.0 & 1 \\
\hline Cassia senna & Forbs & 0.0 & 1 & 0.0 \\
\hline Senna obtusifolia & Forbs & 1 & 1 & 15 \\
\hline
\end{tabular}




\begin{tabular}{|l|c|c|c|c|}
\hline Corchorus olitorus & Forbs & 0.0 & 0.0 & 1 \\
\hline Eragrostis spp & Grass & 0.0 & 0.0 & 5 \\
\hline Aristida spp & Grass & 0.0 & 0.0 & 4 \\
\hline Striga hermonthica & Grass & 0.0 & 0.0 & 2 \\
\hline Setaria sphecelata & Grass & 0.0 & 0.0 & 2 \\
\hline Cyperus rotondus & Like grass & 0.0 & 0.0 & 2 \\
\hline Total seeds & & $\mathbf{1 7 7}$ & $\mathbf{1 5 2}$ & \\
\cline { 1 - 3 } Total seeds/m & & $\mathbf{3 5 4 0}$ & $\mathbf{3 0 4 0}$ & \\
\hline
\end{tabular}

Table.5 five dominant species in both relative frequency and soil seed bank in the three sites at Eldebeibat area (South Kordofan State

\begin{tabular}{|l|c|c|c|c|c|c|}
\hline \multirow{2}{*}{ Species } & \multicolumn{3}{|c|}{ Relative frequency\% } & \multicolumn{3}{c|}{ Seed bank/m $\mathrm{m}^{2}$} \\
\cline { 2 - 7 } & \multicolumn{3}{|c|}{ Sites } & \multicolumn{3}{c|}{ Sites } \\
\cline { 2 - 7 } & Clay & Sandy & Gardud & Clay & Sandy & Gardud \\
\hline Shoenfeldia gracilis & 61 & 0.0 & 36 & 29 & 0.0 & 0.0 \\
\hline Zornia glochidiata & 41 & 90 & 18 & 13 & 155 & 0.0 \\
\hline Dactyloctenium eagytium & 40 & 41.5 & 17 & 0.0 & 13 & 0.0 \\
\hline Chloris gayana & 29 & 0.0 & 0.0 & 20 & 0.0 & 4 \\
\hline Chloris preurii & 25 & 0.0 & 21 & 0.0 & 0.0 & 31 \\
\hline Eragrostis spp & 0.0 & 74 & 0.0 & 0.0 & 0.0 & 0.0 \\
\hline Oldenlandia senegalensis & 0.0 & 67 & 0.0 & 0.0 & 0.0 & 0.0 \\
\hline Echinochloa colona & 0.0 & 58 & 0.0 & 10 & 13 & 76 \\
\hline Vossia cuspidata & 0.0 & 0.0 & 59 & 0.0 & 0.0 & 91 \\
\hline Alycicapus vaginalis & 0.0 & 0.0 & 0.0 & 1 & 7 & 3 \\
\hline Acanthospermum hispidum & 0.0 & 0.0 & 0.0 & 0.0 & 5 & 0.0 \\
\hline
\end{tabular}

Table.6 Invaders and exist plants species according to ground observation and interview of respondents

\begin{tabular}{|l|c|c|}
\hline \multicolumn{1}{|c|}{ Species } & Exist & Invader \\
\hline Schoenfeldia gracilis & $\checkmark$ & \\
\hline Dactyloctenium aegyptium & $\checkmark$ & \\
\hline Zornia glochidiata & $\checkmark$ & $\checkmark$ \\
\hline Solanum dubium & $\checkmark$ & \\
\hline Echinochloa colona & $\checkmark$ & \\
\hline Chloris gayana & $\checkmark$ & \\
\hline Chloris preuirii & $\checkmark$ & $\checkmark$ \\
\hline Ipomea spp & $\checkmark$ & \\
\hline Eragrostis spp & $\checkmark$ & $\checkmark$ \\
\hline Sida cordofolia & $\checkmark$ & $\checkmark$ \\
\hline Pennisetum pedicellatum & $\checkmark$ & \\
\hline Oldenlandia senegalensis & $\checkmark$ & \\
\hline Waltheria indica & $\checkmark$ & \\
\hline Aristida spp & $\checkmark$ & $\checkmark$ \\
\hline
\end{tabular}




\begin{tabular}{|l|c|c|}
\hline Cenchrus biflorus & $\checkmark$ & \\
\hline Alycicarpus vaginalis & $\checkmark$ & \\
\hline Fimbristylis dicotomo & $\checkmark$ & \\
\hline Vossia cuspidata & $\checkmark$ & \\
\hline Digitaria gayana & $\checkmark$ & \\
\hline Acanthospermum hispidum & $\checkmark$ & $\checkmark$ \\
\hline Senna obtusifolia & $\checkmark$ & $\checkmark$ \\
\hline Digitaria gayana & $\checkmark$ & \\
\hline Cenchrus ciliaris & $\checkmark$ & \\
\hline Xanthium brasilicum & & $\checkmark$ \\
\hline Senna ocidentalis & & $\checkmark$ \\
\hline Amaranthus viridis & & $\checkmark$ \\
\hline Datura strammonium & & $\checkmark$ \\
\hline
\end{tabular}

Fig.1 Map of Sudan and South Kordofan State illustrates the study area

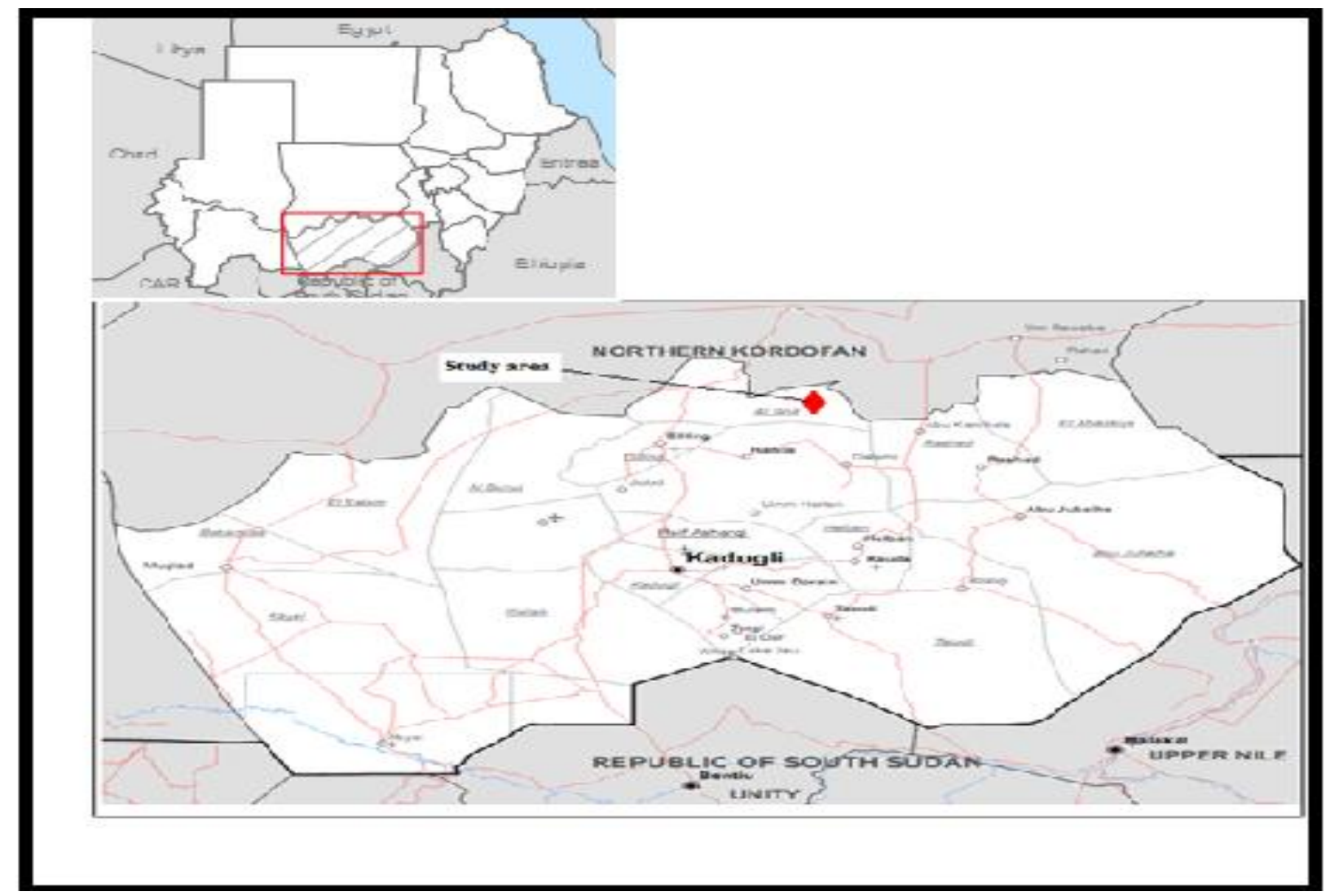

Source: OCHA, 2013 
Fig.2 Average percentage of soil organic matter content of the three sites at Eldebeibat area (South Kordofan State)

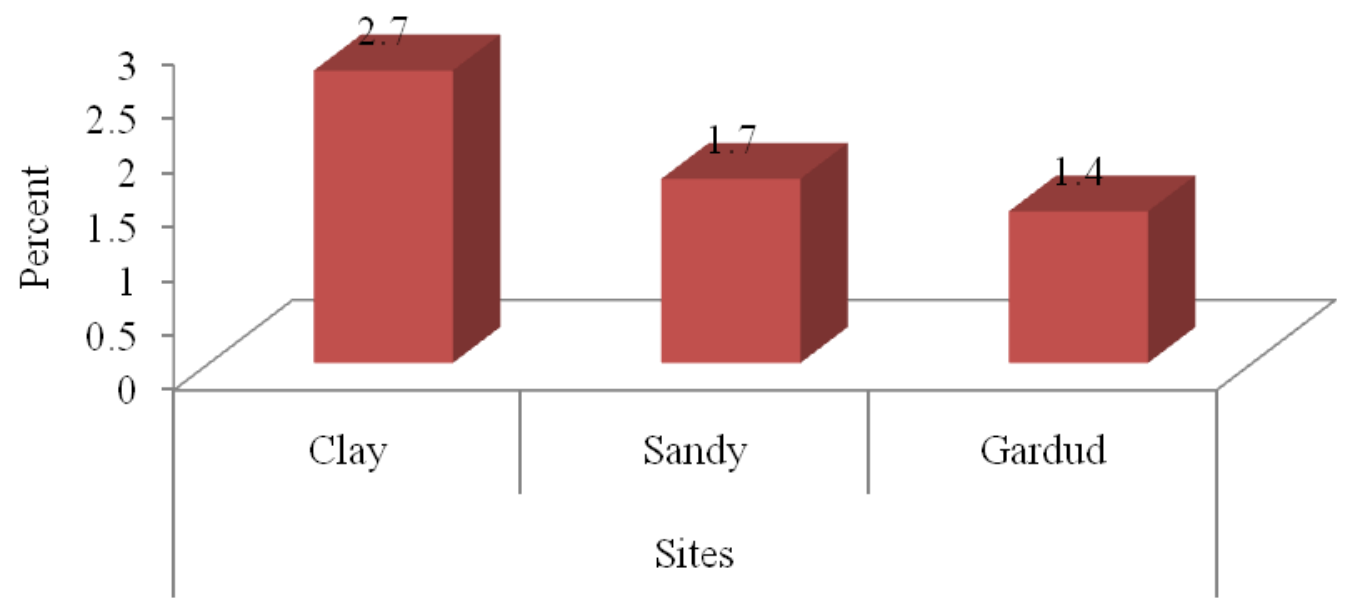

Table (6) Invaders and exist plants species according to ground observation and interview of respondents

The study conclude that three sites dominated by different species in seed bank and vegetation cover, such as Schoenfeldia gracilis consider dominant species in the clay site in the vegetation cover and seed bank as live seeds and Echinochloa colona as dominant species in dead seeds, sandy site dominated with Zornia glochidiata in vegetation cover and seed bank, while Echinochloa colona dominated in dead seeds, and gardud site dominated by Vossia cuspidata in the vegetation cover and seed bank. the area was invaded by species such as Xanthium brasilicum, Datura strammonium, Acanthospermum hispidum, Senna ocidentalis, Amaranthus viridis, Zornia glochidiata, Chloris preuirii, Sida cordofolia, most of them either undesirable or poisons for majority kinds of livestock there was strong signs of rangelands' deterioration, this requires quick interventions to control and reduce spreading of invader plants species in the rangeland, particularly in the northern parts of State. The three sites scored low soil organic matter content that is due to low vegetation cover in the three sites and this led to reduction of organic matter content. The absent of legumes species also contributed to reducing organic matter contents. Consequently the study recommended to considering the assessment of seeds of herbaceous and vegetation cover in account, when decided to practice rangeland improvement programs, particularly seeds broadcasting and. Moreover, the study recommended to increase organic matter contents in the area through planting of legumes trees and shrubs, broadcasting the seeds of legumes herbaceous and avoids early and intensive grazing in the area.

\section{References}

Ball, D.A. 1992. Weed seed bank response to tillage, herbicides, and crop rotation sequence. Weed Sci., 40: 654-659.

Barber, S.A. 1984. Soil Nutrient Bioavailability: A Mechanistic Approach. Wiley New York. 
Brady, N.C. 1974. The Nature and Properties of Soils. Macmillan Publishing Co, New York.

Carmona, R. 1992. Problemática e magnéto de bancos de sementes de invasorasem solos agrícolas. Planta Daninha, 10(1/2): 5-16.

Carvalho, P.C. Favoretto, de F., Impacto, V. 1995. Das reservas de sementes no solo sobre a dinâmica populacional daspastagens. Informativo Abrates, 5(1): 87-108.

Cavers, P.B., Benoit, D.L. 1989. Seed banks in arable land. In: Leck, M.A., Parker, V.T., Simpson, R.L. Eds. Ecology of soil seed banks, London: Academic Press. p.309-328.CBS - website http://www.cbs.gov.sd. Census 2008.

Clements, D.R., Benoit, D.L., Murphy, S.D., Swanton, C.J. 1996. Tillage effects on weed seed return and seed bank composition. Weed Sci., 44: 314-322.

Cordon, J.I. 2007. plant-animal interactions in complex communities: from Mechanism to modeling, Macauly land use research institute, craingiebuckler, Aberdean. Ab15 8QH.UK: Inlemaire, G, Nabinger, C, Hoddgson, J. and Carvalho, F.C 2007. Grassland Eco physiology and Grazing Ecology, CABI Head office, Nosworthy way, Wallingford, Oxfordshire OX108E, UK.

Dessaint, F., Chadoef, R. and Barralis, G. 1990. Etude de la dynamique communauté adventice: III. Influence a long terme des techiniques culturelles sur la composition spécifique du stock semencier. Weed Res., v.30, n.5, p.319-330.

Fashir, G.A. 2014. Impacts Assessment of open Grazing System on Some Range land Environmental Components. Case study El Dilling locality. PhD. Thesis in Range Sciences. Sudan
University of Science and Technology. Khartoum, Sudan.

Martins, C.C. and Silva, W.R. 1994. Da. Estudos de bancos de segmentes do solo. Informativo Abrates, v.4, n.1, p.49-56.

Office of Coordinate on Humanitarian Affairs. (OCHA). 2012. Khartoum, Sudan.

Plaster, E.J. 1996. Soil Science and Management. 3rd ed. Delmar Publishers. Albany.Pp.14-16: in Nefzaoui, and El Mourid, M. 2008) Rangeland Improvement and Management in Arid and Semi-Arid Environments of West Asia and North Africa, IFAD, Roma.

Ramadan, D.E. 2001. The Management Indicators of Forested and Open Rangelands in Semi- Arid areas. M.Sc. SUST, Khartoum. Sudan.

Reddy, Krishna, UIC. 2002. Organic matter determination. Engineering properties of soil based on laboratory testing, paper. Repot.

Roberts, H.A. 1981. Seed banks in the soil. Advances in Applied Biology, Cambridge, Academic Press, v.6, 55p.

Rundel, P.W., Gibson, A.C. 1996. Ecological communities and processes in a Mojave desert ecosystem. Cambridge: Cambridge University Press.

SRM. 1989. Society of Range Management. Glossary of terms used in range management 3d ed. Society for Range Management, Denver, CO.

Thompson, K. 1987. Seeds and seed banks. In: Rorison IH, Grime JP, Hunt R, Hendry AF, Lewis DH, eds. Frontiers of comparative plant ecology. London: Academic Press.

Tisdale, S. L. and W. L. Nelson. 1975. Soil Fertility and Fertilizers. 3rd ed. Macmillan, New York. 
Todd S.W. and Hoffman, M.T. 1999. A fence-line contrast reveals effects of heavy grazing on plant diversity and community composition in Namaqualand, South Africa, Plant Ecol., 142: 169-178.
Yenish, J.P., Doll, J.D., Buhler, D.D. 1992. Effects of tillage on vertical distribution and viability of weed seed in soil. Weed Sci., v.40, n.3, p.429433.

\section{How to cite this article:}

Abdelrahim Omer Abdelrahim, Nawal Khidir Nasr Alamin and Abdelaziz Karamalla Gaiballa. 2016. Assessment of Herbaceous Seed Bank and Soil Organic Matter Content in the Three Different Sites in Semi - Arid Rangelands at Eldebeibat Area (South Kordofan State) - Sudan. Int.J.Curr.Microbiol.App.Sci. 5(12): 884-896. doi: http://dx.doi.org/10.20546/ijcmas.2016.512.096 